\title{
THE ADVANTAGES AND ANALYSIS OF THE LOCATION OF BRANCHLESS BANKING IN URBAN AND RURAL AREAS IN YOGYAKARTA SPECIAL REGION, INDONESIA
}

\author{
Rini RACHMAWATI, Nur Mohammad FARDA, R. RIJANTA, Bowo SETIYONO \\ Universitas Gadjah Mada, Yogyakarta, Indonesia
}

\begin{abstract}
Branchless banking is a banking service based on ICT, one of which is an agent This service can be found in both urban and rural areas. This research aims at identifying the existence and advantages of agents-based branchless banking. The locations of branchless banking agents was also analyzed to explore the spatial pattern. This research applies a quantitative method. Agents and customers are selected by undergoing a survey. The data are obtained by structurally interviewing agents on the kinds of services they provide and the benefits of services for customers. Meanwhile, an accidental sampling technique is used to select customers. Besides, spatial analysis is applied using kernel density analysis and accessibility analysis. The result of the research shows that the advantages of branchless banking through agent alter the perception of spatial benefits to access banking services. The space for banking services is in the same place for other purposes such as business units and home. In urban areas, the making use of agents is mainly based on the factors of being closely located and easy to access. Meanwhile, in suburban and rural areas, conveniences are of primary consideration to make use of agents. Concerning the geographical field, location plays an essential role in the substantial changes related to the spatial functions of economic services, mainly banking services, which are not always located in downtown areas. On the contrary, it is possible to locate economic services in rural areas, with the help of ICT-based services. The result of the analysis shows that banks do not optimally consider location, range and service area for branchless banking represented by agents.
\end{abstract}

Key Words: location, urban, suburban, rural, branchless banking, agents.

\section{Introduction}

In the past, for serving customers, banking services still applied conventional ways. One example is that they had to head for the location of a bank for every transaction they made. Therefore, to get a banking service, customers had to do physical motion, meaning that means of transportation, transportation cost, and time had to be spent. The farther the location of a bank was, the higher the cost and the longer the time would be to reach the bank.

Today, Information and Communication Technology (ICT) has experienced rapid improvement. Information and Communication Technology is defined as a means of technology and its applications in an electronic process to transmit information for various uses (Cohen et al. 2002). Moreover, the application of ICT has dramatically improved and it led to penetration in various occupations and lifestyles (Cohen et al. 2002); one of them is related to bank sector. The use of ICT is also giving some impact on location decentralization, especially for settlement, firm, and office (Rachmawati 2013, Rachmawati et al. 2015).

The benefit of ICT, such as telephone, handphone, internet, and ATM (automatic teller machine), is a great help for people to meet their need for banking services (Rachmawati 2009). There is no need for them to go to the bank for doing transactions since they can go to the nearest ATM from either home or workplace (Rachmawati and Rijanta 2012).

Information and communication technology has become a global trend and it influenced the 
world of business like service by using internet (Bhat et al. 2003). Revolution in technology has changed human life related to time and place, mainly for the application of ICT, such as ebanking and electronic cash transfer (Stilwell 1992), and also the work pattern that is shown by the change of work hour, location and manner (Rachmawati et al. 2010). E-banking services enable people to receive banking services without doing any movement and giving some impact on less movement of people, time and cost as well (Rachmawati and Rijanta 2012). This service is also used by the small medium enterprises sector that makes trade transaction easier (Rachmawati et al. 2018).

E-banking and also ATM are included in branchless banking services. Muthinja and Chipeta (2018) mention that mobile banking is also involved in branchless banking innovations, other than that, internet banking and ATM and agency banking as well. E-banking is not easy enough to be used by certain people who do not have access to these services, especially for people in the suburbs and rural areas. A service is needed that makes it easy for people to access, and one of them is branchless banking system through an agent. In the last two decades, a lot of banking innovation has taken place to improve the financial performance of commercial banks (Dzombo et al. 2017). Branchless banking which involves the use of agency banking and electronic banking channels in the distribution of banking products and services is one such innovation (Dzombo et al. 2017).

The application of branchless banking is not only found in developed, but also in developing countries. Brazil, for example, has 150000 service points, meaning five times the number of banks and contributing to $80 \%$ of the social benefits from the government for more than 40 million people with limited or no access at all to banking services (Jayo et al. 2012). The development of branchless banking will result in potential benefits to stakeholders in many different forms, such as a program that is more effective for social benefits, an increasing number of payment for electricity and water bills, and a better return for bank loan (Ivatury 2006, Diniz et al. 2009, Jayo et al. 2012). Branchless banking brings much-needed financial services to the unbanked in the developing world (Reaves et al. 2015). Ansong et al. (2015), for instance, argue that the disproportionate growth of physical/traditional branch banking leads to disparities in the spatial distribution of bank branches. They conclude that branch banking needs modernization through the development of electronic infrastructure such as mobile phone banking, offering more attractive, efficient, and cost-effective operations. Branchless banking will help Indonesia to decrease its number of unbanked people (Shabirah and Aldianto 2014). Leveraging ubiquitous cellular networks, these services are now being deployed as smartphone apps through providing an electronic payment infrastructure (Reaves et al. 2015).

Several banks in Indonesia have introduced branchless banking services, mainly to make it accessible in providing services for the people who find difficulty getting physical banking services. Such people are those, especially, who live in rural areas. Therefore, the existence of agents is expected to meet their need. The banking industry is required to improve its financial services for the benefits of people. According to Otoritas Jasa Keuangan (2014), the low rate of accessing financial services in Indonesia is caused by, among others, the large number of areas with limited banking services, the low income of the majority of people, and the low financial literacy of people on products and financial services. The branchless banking program is implemented to enlarge access of people to banking services and, at the same time, to be one of the front liners in improving the financial literacy with the helping role of agents (marketing roles). The success of this program can also be determined by the stipulations of location and access, the ease of use, or the perceived benefits.

This research aims at identifying the existence and advantages of agents-based branchless banking. The locations of branchless banking agents were also analyzed to explore the spatial pattern. This research is implemented by comparing branchless banking services through agents in urban, suburban, and rural areas. Furthermore, how the implementation of 
branchless banking in those three areas is and what the characteristics of location and physical condition of areas are will also be of concern for this research. The information from the research result can give a new perspective on the bank, especially as an input to develop branchless banking in urban and rural areas as well. Research on branchless banking is very important in order to provide information that will help policymakers and practitioners to focus their continued efforts on creating an enabling environment for branchless banking (Dermish et al. 2012).

\section{Methodology}

This research was carried out in urban, suburban and rural areas of Yogyakarta Special Region. The study area has been served by branchless banking system through an agent from the Bank. The obtained information is primary data by doing field observations and structured interviews. The agents were structurally interviewed on the kinds of services they provide and the benefits to the customers. To select the agents, a survey was done until the location of agents was found. In addition, a structured interview with the customers was also done to obtain data on the benefits of branchless banking. The accidental sampling technique was used to choose the respondents as customers of branchless banking. Accidental sampling is a type of nonprobability sample. Sampling was carried out by selecting the cases at hand until the desired number of people/items was reached (Wilson 2014). Data collecting from the respondents stopped when the information was already saturated. Meanwhile, spatial analysis was applied by using GIS to find out the distribution of agents and customers, and it was associated with the physical condition of areas and accessibility, namely through kernel density analysis (Silverman 1986) and the accessibility analysis workflow (Fig. 1).

The agents and customers of branchless banking coordinate locations used as input for spatial density analysis. The density analyses calculated an appropriate search distance for determining the neighborhood size and to classify the output as an equal interval with five classes, and to provide the output densities in square kilometers (Silverman 1986). The other geographic perspective was the accessibility analysis using the weighting overlay (Road + Settlement + Slope). This analysis developed from combining the Euclidean distance of road and settlement (the closer it is, the value is higher), and slope (the more flat it is, the higher are the values). Accessibility Map delivers from the addition (+) of Euclidean Distance to Road, Euclidean Distance to Settlement, and Slope. The zero value (0) indicates low accessibility, and the value of three indicates high accessibility.

\section{Results and Discussion}

\section{Overview of branchless banking}

ICT has benefited to improving, among others, comfort, ease in mobility, and efficiency in cost and energy (Nam and Pardo 2011). Therefore, the development in information and communication technology is required to facilitate all activities carried out by the government, companies, and citizens.

In developing countries, innovation has helped government to reduce poverty, to push development in economic sectors, and to increase financial access for poor and low-income families (Karlan and Morduch 2010). For example, the application of ICT in banks (e.g. branchless banking) is not only able to increase financial access for society, but also, at the same time, it offers other financial services for them. These are, for example, cash flow management, saving, and deposit, money transfer, bill payment, or other benefits related to financial aids from the government. Branchless banking is now regarded as a practical approach to enlarge financial services in remote regions where there are hardly any bank branches (Mas 2009). The most important aspect of branchless banking is the availability of ICT to enable banks and their clients to be connected with the help of agents that have different 


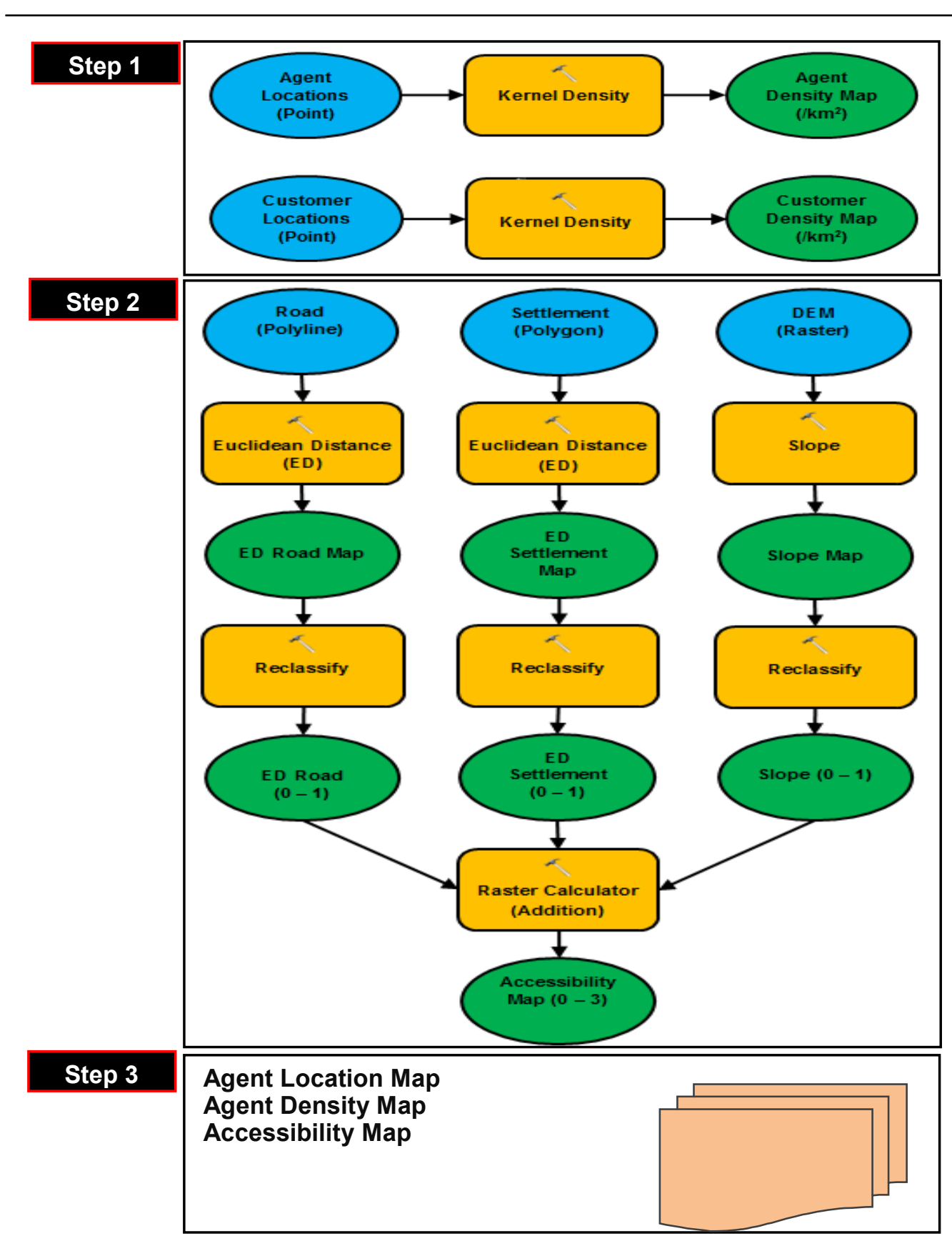

Fig. 1 - Agent and Customer Branchless Banking Kernel Density Analysis and Accessibility Analysis Workflow 
The Advantages and Analysis of the Location of Branchless Baking in Urban and Rural Areas in Yogyakarta Special Region, Indonesia

backgrounds and come from different places (Jayo et al. 2012).

In the banking sector, the development of ICT has changed the traditional brick-and-mortar banking or single channel model into the more ICT based or multi-channels model, for instance, ATM and internet banking (King 2018). Physical bank branching can be very costly especially when the branch's catchment area lacks the substantial depository base and potential borrowers. Such provision not only supports the promoting of financial inclusion in an economy but it also enables banks to provide their services at more affordable costs that eventually lower the prices to the customers. ICT, however, leads to many bank closures and consolidation (The Economist 2002).

Another strand of literature argues that the ICT based banking, hence branchless banking, will have disadvantages to accumulate valuable know-how about market and business opportunities in the targeted area because they are not able to interact directly or personally to the potential borrowers/depositors. In other words, banks need to be geographically closer to their market in order to collect and to extract important soft information in addition to hard information, especially from the borrowers (Agarwal and Hauswald 2010). Furthermore, operating branch office closer to their customers would build stronger lending relationships and credit quality (Udell 2009).

The presence of agents in the branchless banking might be regarded from the spatial attractiveness that they offer more convenience to the respective markets. Such geography proximity will attract customers because bank products and services now became spatially available in a short distance. Hinson et al. (2009), for example, find that proximity is one of the most important determinants of bank choice. Branchless banking has become an important innovation offering various benefits to their customers and it eventually improved the banks' financial performance (Muthinja and Chipeta 2018).

There are several notions of branchless banking, as stated below:

"Branchless banking is about building a general payments infrastructure that allows people (...) to deposit and withdraw funds and make electronic payments (...), thus eliminating the need for bank branches (...)" (Dermish et al. 2012: 82).

"Branchless banking is a modern mechanism to facilitate financial services in developing regions. There is a considerable growth taken place in branchless banking services in India, despite this, branches are unlikely to die, despite ATMs, laptops and smartphones becoming primary platforms for daily banking" (Anand and Sreenivas 2013: 1).

"Branchless banking is a distribution network that delivers financial services outside of conventional bank branches through technology and alternative networks with more effective and efficient costs as well as offering security and convenience" (Otoritas Jasa Keuangan 2014: 74).

In general, branchless banking services are applied to increase the financial access of the society and to support the efforts for the even distribution and development of bank services. In this case, the role of agents is as an operator of branchless banking program. Agents serve as the side cooperating with an operating bank that is in charge of providing bank services. The branchless banking program is expected to be able to reach those who are not able to be served by a bank office network in a physical way (Otoritas Jasa Keuangan 2014). Instead, it makes use of the means of information technology in the forms cellular phone, Electronic Data Capture (EDC), and internet banking. As a result, the application of technology can reduce costs and the time that people spend in doing their financial transaction. 


\section{Branchless banking services provision}

The branchless banking program is a type of financial services without offices by enlarging the bank service coverage without physically opening a new branch. In Indonesia, it is known as Laku Pandai (Otoritas Jasa Keuangan 2017). Laku Pandai means: Officeless Financial Services for Inclusive Finance, a program of the Financial Services Authority Program for the provision of banking services or other financial services through cooperation with other parties (i.e. bank agents), and supported by the use of information technology facilities (Otoritas Jasa Keuangan 2017). It is implemented by making use of technological media as well as help from agents, such as shops, post offices and individuals (Otoritas Jasa Keuangan 2017).

Based on the POJK Number 19/POJK/03/2014 on financial services without an office in the framework of inclusive finance, this regulation enables a bank to have an authority to cooperate with agents serving as the extension of the bank in providing services to customers, ranging from an account opening to an account closing (Otoritas Jasa Keuangan 2014). Branchless banking service that is regulated on POJK Number 19/POJK/03/2014 is a saving product with the characteristic of Basic Saving Account (BSA) and credit/payment to micro customers, and other bank services as well:

"Branchless banking in Indonesia is led-by bank. There are two aspects of suitable model of branchless banking in Indonesia, which are from technology and regulation. Technology: Technology in branchless banking is using mobile mini ATM (...). Regulations: there are two regulations in branchless banking (...), which are through retail agent, such as cooperation, shops, and village hall. The second method is branchless banking by bank officer who comes to customer place" (Shabirah and Aldianto 2014: 644).

Based on the Regulation of Otoritas Jasa Keuangan (2014) on Financial Services Outside Office, article 4, the kinds of service products that agents can serve to customers are saving, loan for micro customers, micro insurance, and other services that Otoritas Jasa Keuangan approves. Saving service at an agent is just like the one that a bank office provides, for example, saving, withdrawal, and transfer/remittance. Loan service or financing for micro customers constitutes the one in the forms of giving loan and/or loan return. Microinsurance service is a kind of insurance product intended for low-income people. Meanwhile, other services include the distribution of financial aids and other bank services. The network to facilitate branchless banking needs to meet the following essential elements (Mas 2009): (1) A retail shop that is easy to access for customers, (2) Electronic infrastructure that makes the fast transaction possible, and (3) Account platform in the bank to retain and accomplish the transaction record.

Based on the Otoritas Jasa Keuangan's data in 2017, there are 22 banks that provide branchless banking services in Indonesia. Meanwhile, the results of the survey in the areas where this research was carried out showed that six banks provide branchless banking services. They are: BTPN, BTPN Syariah, BRI, BRI Syariah, BNI, and Mandiri.

\section{The existence and the use of branchless banking}

The results of the survey show that there is a difference in terms of the number of agents and customers in urban and rural areas. In the city of Yogyakarta, there were 58 agents found, with 30 agents in the suburbs of Yogyakarta, and 67 agents in the Regency of Kulon Progo. Compared with the city of Yogyakarta and the suburbs of the Regency of Sleman, the Regency of Kulon Progo, where most of its areas are rural areas that are located relatively far from the business center and bank offices, has the most number of agents. This is confirmed by a statement of Franksiska et al. (2017) who mention that branchless banking technology was easy to learn and easy to operate, even for the rural community. Meanwhile, the number of 
customers was obtained based on the finding results when doing field surveys by using accidental sampling. In the city of Yogyakarta, 36 customers were found, 30 customers in the suburbs of the city of Yogyakarta, and 41 customers in the Regency of Kulon Progo.

The increasing number of branchless banking agents is the result of the offer made by banks to be an agent in each area. Besides an offer made by banks, the government program of distributing aids to a certain group of families is another factor that makes the number of agents increase, especially in the city of Yogyakarta. The average length of period to be an agent of branchless banking is one year. However, several agents have been active for three years as found in the Regencies of Kulon Progo and Sleman. Fig. 2 shows the reasons for becoming an agent. They are, among others, receiving an offer from bank, proposing to be an agent, and being appointed by the bank. Meanwhile, Fig. 3 shows data on the length of period to be an agent, which is between one and three years.

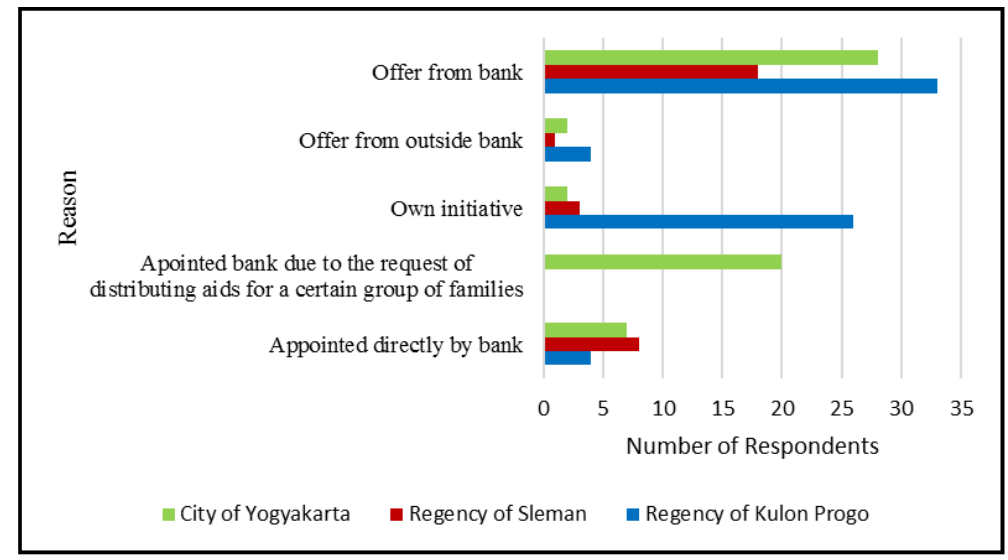

Fig. 2 - Reasons for becoming an agent

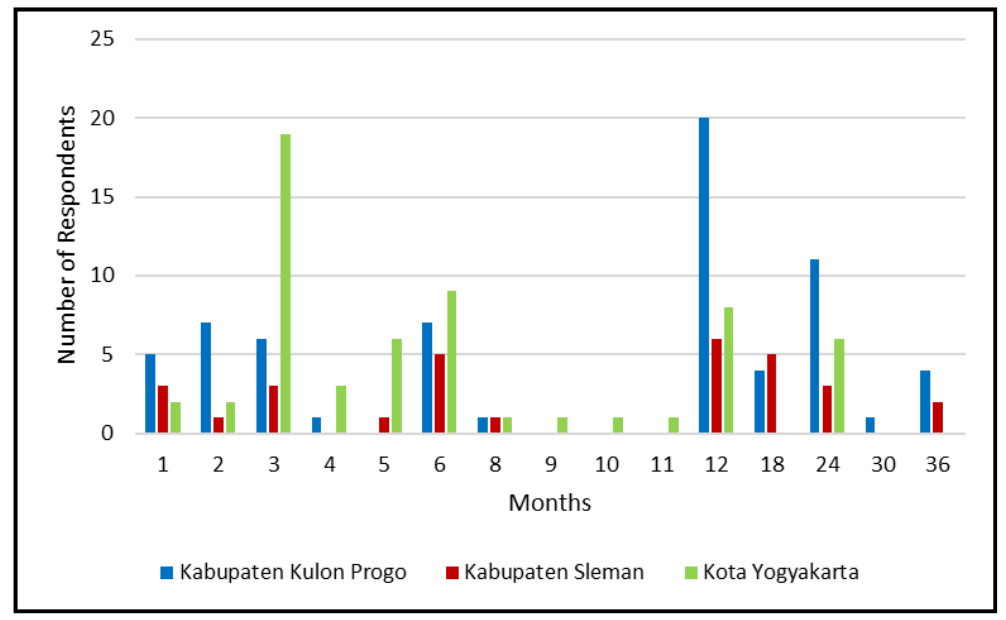

Fig. 3 - Length of period to be an agent 
The frequency of benefiting of an agent shows a difference between rural and suburban areas. In rural areas of Kulon Progo, 30 transactions are made daily. Meanwhile, ten transactions are daily made in the city of Yogyakarta and five transactions in the suburban areas belonging to the Regency of Sleman (Fig. 4). The average agent, irrespective of the difference, reveals that at least one transaction is made daily in each area. The most dominant transaction in the city of Yogyakarta is cash saving and aid disbursement for certain group of families. Meanwhile, in the suburban areas, cash saving and transfer are dominant transactions and, in rural areas, cash saving and payment for electricity bill are very dominant (Fig. 5). The success of branchless banking in Kenya does show that there is a real customer demand for convenient money transfers and payments and, to a lesser extent, savings (Dermish et al. 2012). Concerning the benefiting branchless banking services, the average customer has made use of them for one year, with the longest of three years (Fig. 6).

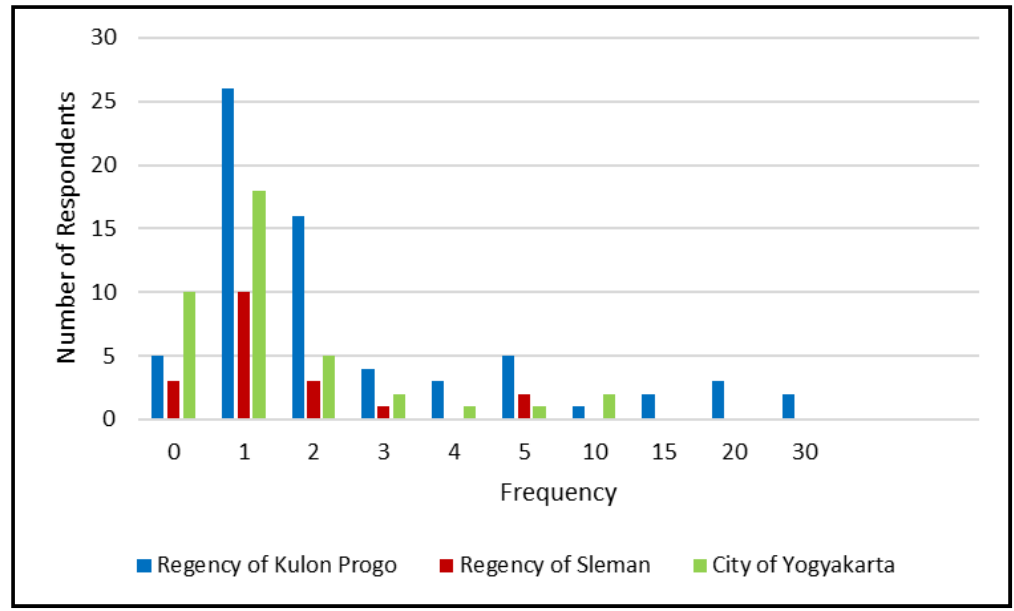

Fig. 4 - Frequency of daily transactions according to agents

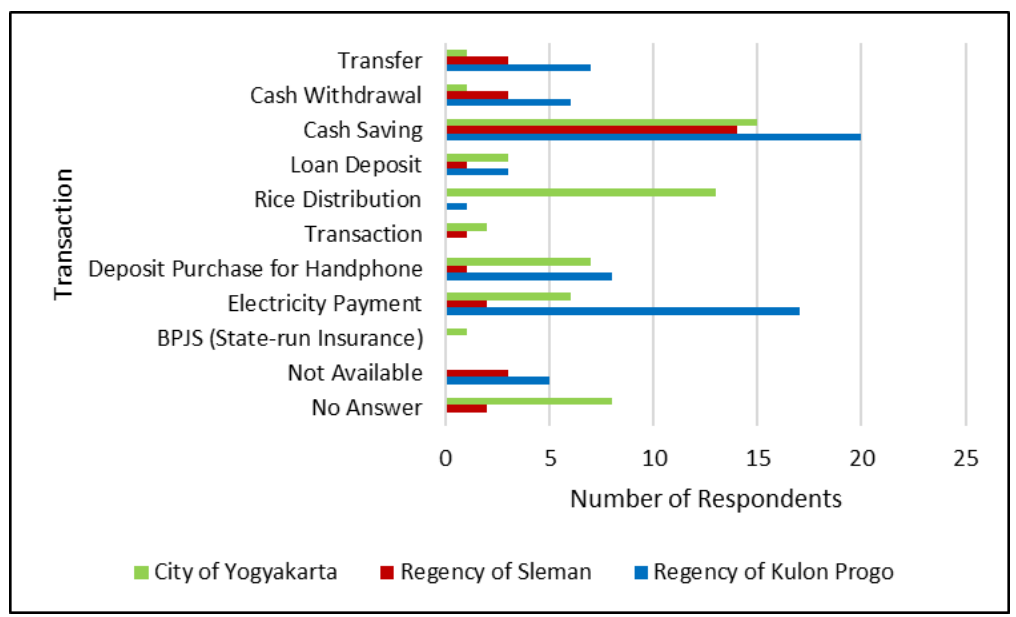

Fig. 5 - Kind of most frequently made transactions according to agents 


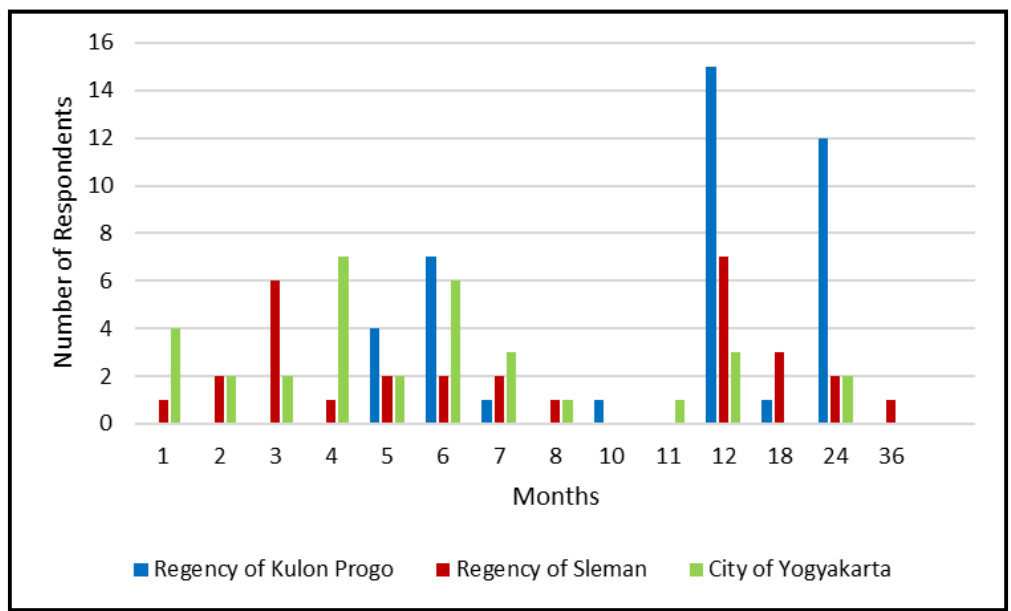

Fig. 6 - Length of period to be a branchless banking customer

The result of the interview with the customers shows that they make transactions once a week. Several customers make a transaction only when they feel the need, so that their intensity is not measurable. In urban areas, several customers go to see the agent at the time when there is an aid distribution. Meanwhile, cash saving is the most dominant transaction that the customers make in the three areas of research. Besides this, deposit purchase for handphone and electricity and aid distribution from the government are the second dominant transactions after cash saving.

\section{The Benefits of branchless banking in urban, suburban, and rural areas}

The results of the research show that the advantages of becoming an agent are that he can get extra income, increase his business reputation, and receive some bonus and facilities. The agent's income rises because of the profit he makes from every transaction made by the customers. Besides this, customers also tend to buy something in the agent's shop because most agents also run other businesses. Bonus and facilities are also given by the bank to the agent. Several agents in the suburban areas reveal that an advantage they can make by becoming an agent is that they can help people in their surrounding areas.

The main benefit that most customers feel because of the presence of branchless banking services is that they can save their time since the agent is closely located to their home. The percentage of respondents making such a statement is as follows: $34 \%$ in the city of Yogyakarta, $34 \%$ in the suburban of Yogyakarta, and $24 \%$ in the rural areas of Kulon Progo Regency. Meanwhile, the second benefit that most customers feel is that they can save their travel costs in those three areas, as follow consecutively: $21 \%, 26 \%$, and $21 \%$. The other benefit that most customers feel is eventually that the service can be given at any time, even on holidays, not being limited by office hours. Related to the advantages of time flexibility in utilizing branchless banking, it can be said that this service improves the services of banks that are limited by time. The research results from Shabirah and Aldianto (2014) about the respondents' perception towards banking evidence that the bank is considered secure, but the problem is that the bank does not have flexible opening hours. Meanwhile, branchless banking services through this agent are seen as providing flexible services in terms of time. Customers are even able to make transactions like cash saving even with a small amount of money. Besides, a sense of cohesiveness and convenience are also felt by the customers (Fig. 7, 8, 9). 


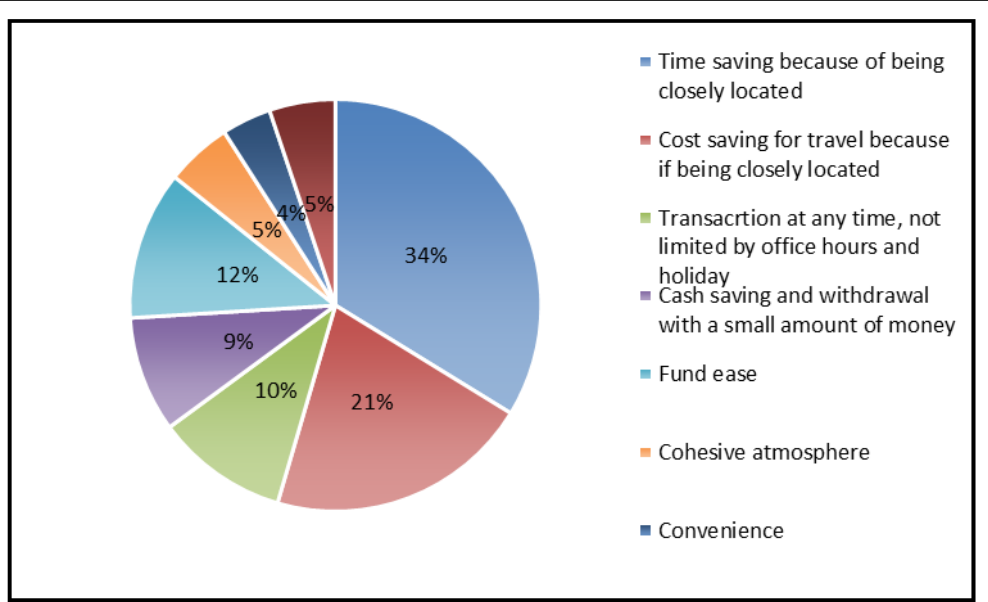

Fig. 7 - Benefits mostly felt by the customers in the city of Yogyakarta

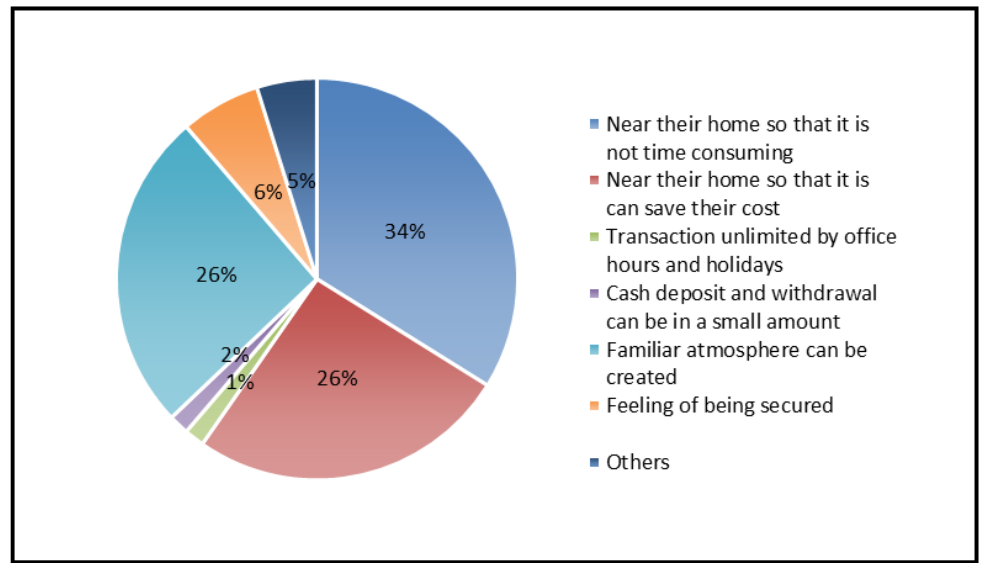

Fig. 8 - Benefits mostly felt by the customers in the suburban areas of Yogyakarta

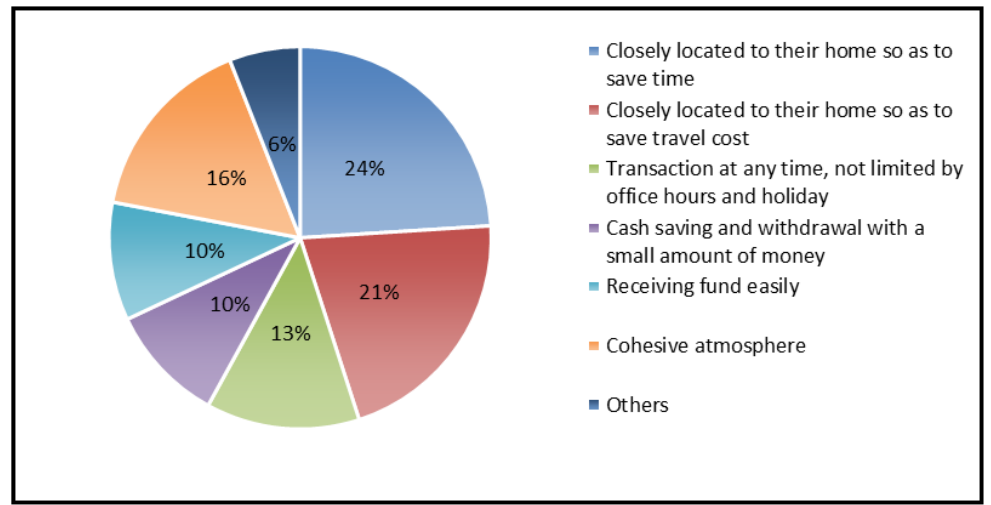

Fig. 9 - Benefits mostly felt by the customers in the rural areas of Kulon Progo Regency 
Regarding the benefits of using branchless banking, a part of the respondents mention that they get a cohesive atmosphere and the feeling of being secure and convenient. Reaves et al. (2015) also mention about the security reason in using branchless banking. By enabling access to a cashless payment infrastructure, these systems allow the residents of such countries to reap the benefits afforded to modern economies and to decrease the physical security risks associated with cash transactions (Reaves et al. 2015). Although people in rural areas still have some anxieties, such as scams, the community's intention to adopt a branchless banking technology is quite high (Franksiska et al. 2017). In Pakistan, consumers perceive risks such as the misuse of financial information which hinder them from adopting mobile banking services. Therefore, the mobile banking service providers need to plan a higher security in providing services in order to achieve a higher consumer acceptance (Kazi and Mannan 2013). Regarding the branchless banking services, namely the agents present more trust factors because most of service users recognize them (in the case of rural areas, agents are their neighbors). Agents usually work in grocery stores, handphone credit counters, photocopies or another stores. Besides that, it is also because the transactions they do are mostly small transactions, such as electricity payments, handphone credit purchases, and loan installments so that the perception of risk does not appear as a problem in using branchless banking-agents.

Otherwise, Abbas et al. (2015) mention about how to create a good service both from policymakers in the bank sector and from the relevant parties as well:

"It can be suggested from our findings that the most important factors of service quality are service reliability, responsiveness and assurance. Policy makers in branchless banking should pay more heed to increase the reliability of service. (...) Factors such as responsiveness and assurance can be addressed by SBP regulations, banks and the third parties that implement and execute the branchless banking. (...) In addition, there is a need to grow digital literacy among the non-users of branchless banking which will augment the number of users in future" (Abbas et al. 2015: 1490).

To develop branchless banking in Indonesia, we should consider the values of the society, its religion, and beliefs, the community willingness, the local wisdom, and the tradition and culture of a wide area as well (Santoso and Ahmad 2016). In addition, this research adds another factor which is necessary to consider, i.e. location and accessibility.

\section{The location analysis of branchless banking services}

Location is the main factor for customers to make use of branchless banking services. Being closely located to the agent of branchless banking services from their home is the biggest benefit that customers get. In every sub-district of the city of Yogyakarta, an agent of branchless banking services is found. The agents are mostly found quite far from the business center and downtown area, like the ones found in the sub-districts of Kotagede and Umbulharjo (Southern part of Yogyakarta city). Both sub-districts are also densely populated. The existence of agents in the city of Yogyakarta shows that they are found in the settlement areas located on the sides of collector roads and artery roads connecting every sub-district and the surrounding regencies of the city of Yogyakarta.

The presence of agents in the rural areas of Kulon Progo Regency has different characteristics in their distribution if compared with that in the urban and suburban areas. The agents in the Regency of Kulon Progo are mostly found in the settlement areas of rural areas, particularly the ones located far from the city center. The density of the agent's locations is also found on the sides of artery roads, though not as many as those on collector roads. There are several agents found on the roadsides of villages, though the number of them is smaller than that on the sides of arterial roads. In the Regency of Kulon Progo, the agents are mostly found in the 
sub-districts of Panjatan, in the Sothern part of Kulon Progo Regency, and Kalibawang, in the Northern part of Kulon Progo Regency (Fig. 10). The sub-district of Kalibawang is located the farthest from the city center. This proves that the presence of branchless banking services through agents is indeed needed to enlarge the coverage of banking services and the people living in rural areas are able to make use of them.

Meanwhile, in the suburban areas belonging to the Regency of Sleman, the biggest number of agents is found in the sub-district of Depok. This area has rapidly developed because it is located in the suburb of Yogyakarta and there are many university and college campuses and newly-developed residences. The agents are also found on the sides of collector roads in the suburb, for example, the ones found along Godean Street, a collector road in the sub-district of Godean. Running a business on the side of a collector road has benefitted the business owner to improve his business by becoming an agent of branchless banking. It is easy for the customers to reach an agent while being located between the city of Yogyakarta and the Regency of Sleman.

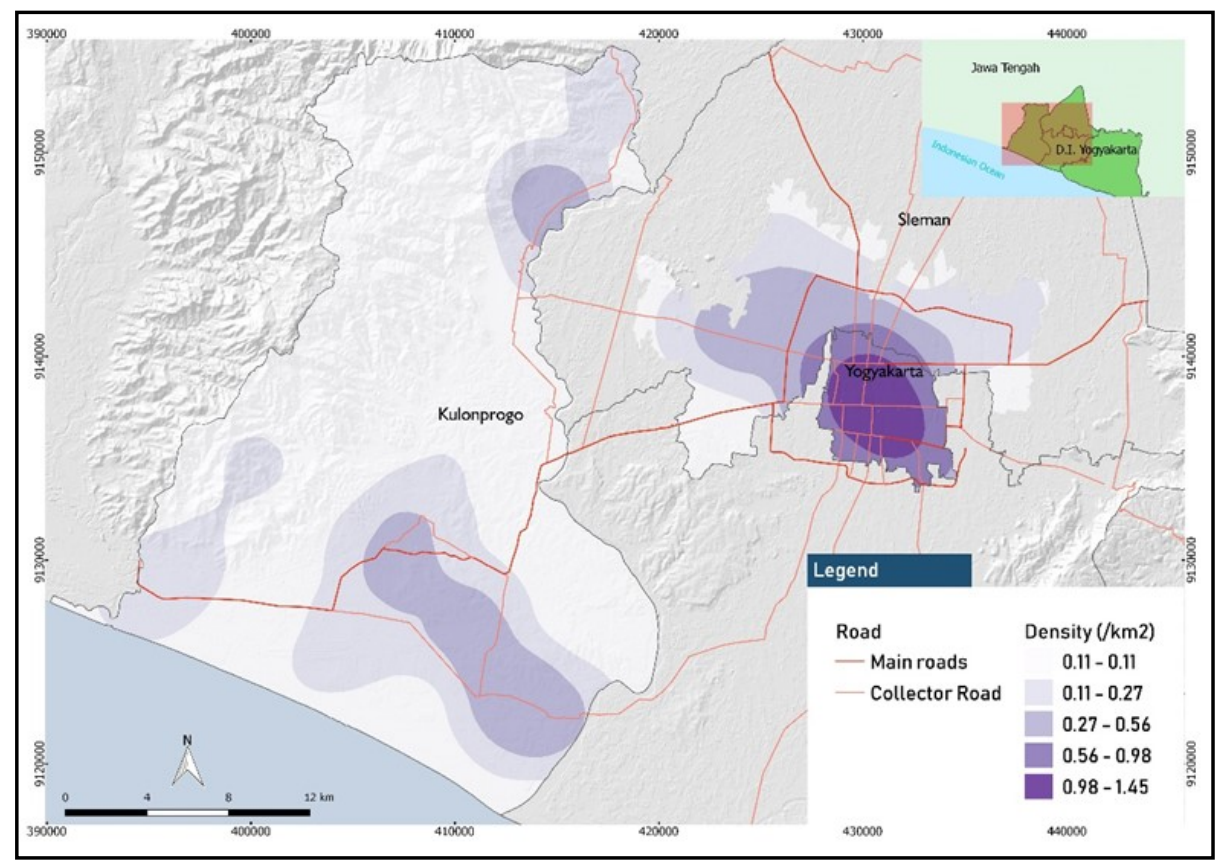

Fig. 10 - Branchless Banking-Agent Density Analysis Map in urban, suburban and rural areas

Fig. 11 shows branchless banking-agent customer density analysis map in urban, suburban and rural areas. The location mapping of customers is based on data collection through accidental sampling. Therefore, the distribution map of customers is not based on the real number of customers in each place of research. This is because the number of customers is only based on the number of service users found at the time of the field survey.

On the density map of the Regency of Kulon Progo, the number of customers is mostly found in the southern part of the regency. Meanwhile, in the suburban areas of Yogyakarta city, the 


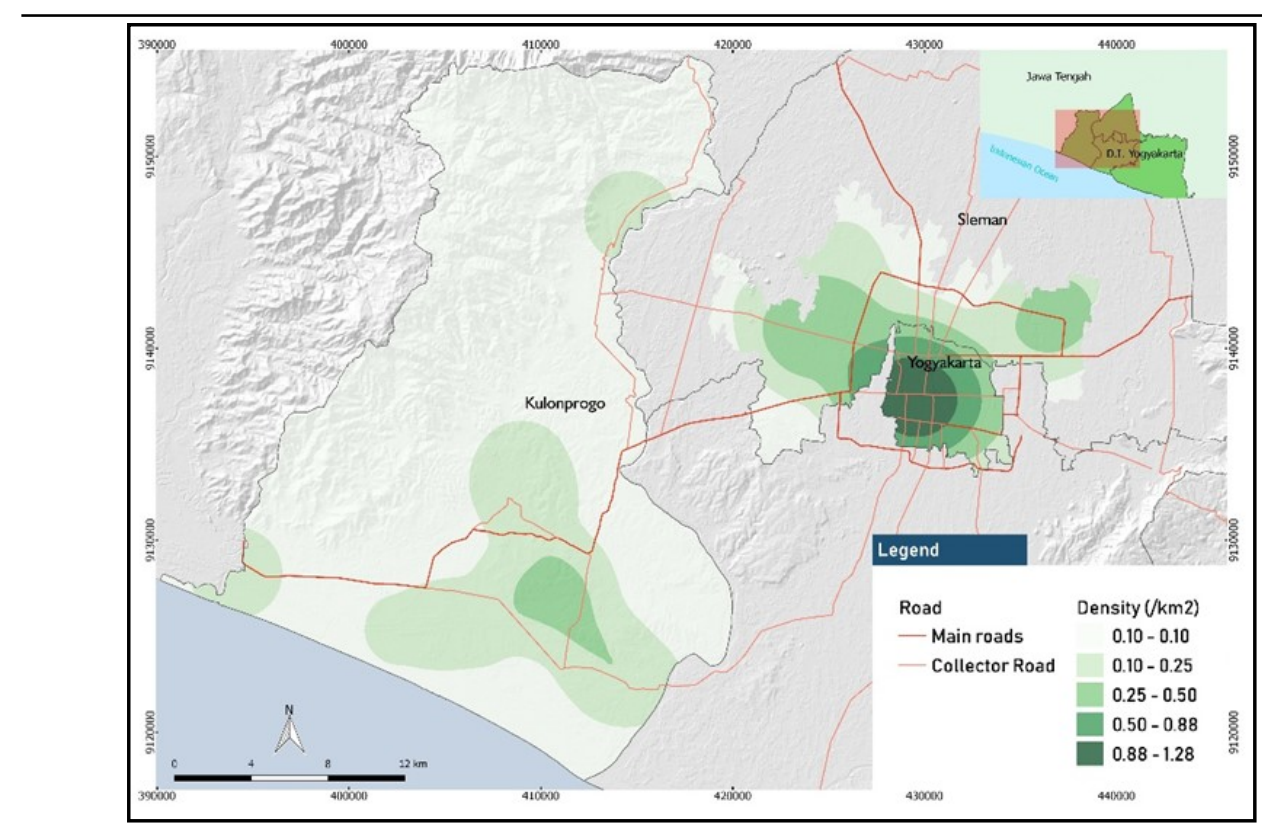

Fig. 11 - Branchless Banking-Agent Customer Density Analysis Map in urban, suburban and rural areas

biggest number of customers is found in the sub-districts of Godean and Depok. The density of customers in the city of Yogyakarta is found the highest if compared with that in other areas. This is because the use of branchless banking services through an agent is effective and customers find closely located to their home the agent of branchless banking services; otherwise there are many bank offices and ATMs found in the city.

The banking activities through an agent can be called running well if there are customers who make use of branchless banking services. Fig. 12 shows that the distribution of branchless banking location is related to its accessibility (topography, distance to the main road, and distance to the settlement). The distribution of agents is seen densely in areas on the sides of arterial or main and collector roads. The distribution of agents is seen densely in areas on the sides of arterial or main and collector roads. The distribution pattern is seen outward or far from the main or collector roads because not all customers live along the sides of both kinds of roads. Meanwhile, the presence of agents in the settlement area is also found so that the distribution pattern of agents density tends to be found in the surrounding areas of the main and collector roads that are getting far from the road.

Location is the main factor for customers to do transactions through agents because they are closer to their home than the nearby bank office. Therefore, the presence of an agent in the settlement area of customers is indeed needed. Besides the accessibility factor, being close to the settlement area, being close to the main road, and being located in flat and slope areas have become important factors for customers to do bank transactions through the agents of branchless banking services.

\section{Conclusions}

The results of the research show that the making use of branchless banking through an agent 


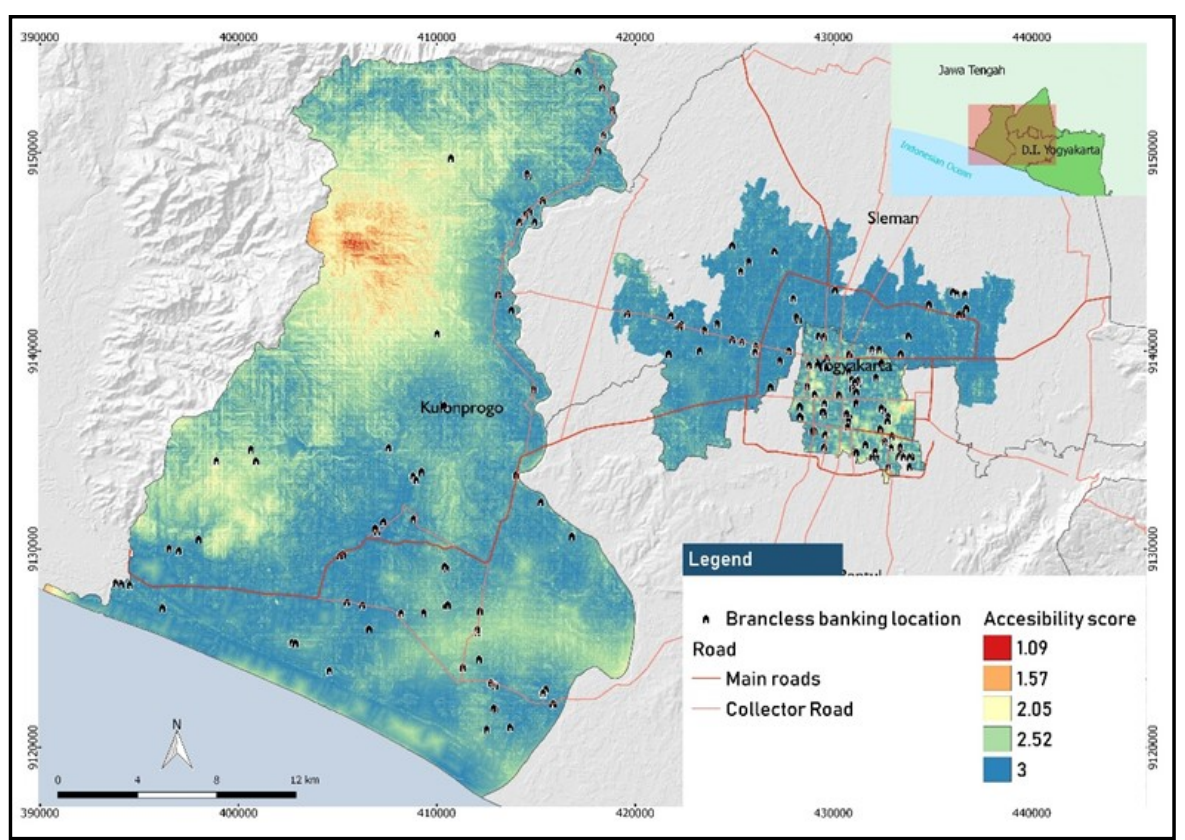

Fig. 12 - Branchless Banking-Agent Accessibility Map in urban, suburban and rural areas

in urban areas is more based on the factors of location close to the customers' home and on easy accessibility. Meanwhile, in rural and suburban areas, besides those two factors, other factors such as cohesive atmosphere and convenience are of primary importance. Agents and customers are mostly found in rural areas than in both urban and suburban areas. Meanwhile, the benefit that the agents get is that they can increase their income. For customers, the advantage that they can get is that they can save their time and costs because the agent is close to their home. The result of map analysis shows that the density of agents and customers is influenced by accessibility while being close to the main road, the settlement, and in areas with flat slope land.

This research proves that branchless banking through an agent that is adopted by banks in Indonesia has given the main benefit of enlarging bank products that were previously accessed only at the branch office of banks (bank branching) while customers had to spend higher costs for transportation. Branchless banking service through an agent is acceptable because it offers benefits to the customers and additional revenues to the agents. Such services will keep growing along with the growth of e-commerce business and transactions due to the increase of ICT use.

\section{Acknowledgments}

The research was funded by PUPT 2017 scheme. We would like to thank Universitas Gadjah Mada and Higher Education Directorate of Indonesia. Thanks also go to the blind reviewers for the comments to improve the manuscript. 
The Advantages and Analysis of the Location of Branchless Baking in Urban and Rural Areas in Yogyakarta Special Region, Indonesia

\section{References}

ABBAS S. S., MEHMOOD B., ABBAS S. F., SAIR S. A. (2015), Quality of Branchless Banking Service in Lahore City: Application of Servequal Model, Sci.Int(Lahore) 27 (2), 14871491.

AGARWAL S., HAUSWALD R. (2010), Distance and Private Information in Lending, The Review of Financial Studies 23 (7), 2757-2788.

ANAND M. B., SREENIVAS D. L. (2013), A Study on Branchless Banking in India, International Journal of Development Research 3 (8), 1-6.

ANSONG D., CHOWA G., ADJABENG B. K. (2015), Spatial Analysis of the Distribution and Determinants of Bank Branch Presence in Ghana, International Journal of Bank Marketing 33 (3), 201-222.

BHAT C. R., SIVAKUMAR A., AXHAUSEN K. W. (2003), An Analysis of the Impact of Information and Communication Technologies on Non-Maintenance Shopping Activities, Transportation Research Part B: Methodological 37 (10), 857-881.

COHEN G., SALOMON I., NIJKAMP P. (2002), Information-communications technologies (ICT) and transport: does knowledge underpin policy?, Telecommunications Policy 26 (1-2), 31-52.

DERMISH A., KNEIDING C., LEISHMAN P., MAS I. (2012), Branchless and Mobile Banking Solutions for the Poor: A Survey of the Literature, Innovations: Technology, Governance, Globalization 6 (4), 81-98.

DINIZ E. H., POZZEBON M., JAYO M. (2009), The role of ICT in helping parallel paths converge: microcredit and correspondent banking in Brazil, Journal of Global Information Technology Management 12 (2), 80-103.

DZOMBO G. K., KILIKA J. M., MAINGI J. (2017), The Effect of Branchless Banking Strategy on the Financial Performance of Commercial Banks in Kenya, International Journal of Financial Research 8 (4), 167-183.

THE ECONOMIST (2002), China - The withering away of the party: Economically, but not politically, Retrieved from: https://www.economist.com.

IVATURY G. (2006), Brazil's banking correspondents, in: Mathison S. (ed.), Electronic Banking with the Poor: Increasing the Outreach and Sustainability of Microfinance through ICT Innovations, The Foundation for Development Cooperation, Brisbane, pp. 53-57.

FRANKSISKA R., PURWATI Y., NUGROHO P. I., WIDODO A. (2017), Driving and Inhibiting Factors of Branchless Banking Technology Adoption in Rural Community, KINERJA 21 (1), 35-47.

JAYO M., DINIZ E. H., ZAMBALDI F., CHRISTOPOULOS T. P. (2012), Groups of services delivered by Brazilian branchless banking and respective network integration models, Electronic Commerce Research and Applications 11 (5), 504-517.

HINSON R., OWUSU-FRIMPONG N., DASAH J. (2009), Key motivations for bank patronage in Ghana, International Journal of Bank Marketing 27 (5), 381-399.

KARLAN D., MORDUCH J. (2010), Chapter 71 - Access to Finance, in: Rodrick D., Rosenzweig M. R. (eds.), Handbook of Development Economics, Elsevier, Oxford, pp. 47034784.

KAZI A. K., MANNAN M. A. (2013), Factors affecting adoption of mobile banking in Pakistan: Empirical Evidence, International Journal of Research in Business and Social Science 2 (3), 54-61.

KING B. (2018), Branches Have a Strong Future as Alternative Channels, BBN Times, Retrieved from: https://www.bbntimes.com.

MAS I. (2009), The Economics of Branchless Banking, Innovations: Technology, Governance, Globalization 4 (2), 57-75.

MUTHINJA M. M., CHIPETA C. (2018), What Drives Financial Innovations in Kenya's Commercial Banks? An Empirical Study on Firm and Macro-Level Drivers of Branchless Banking, Journal of African Business 19 (3), 385-408.

NAM T., PARDO T. A. (2011), Conceptualizing Smart City with Dimensions of 
Technology, People, and Institutions, The Proceedings of the 12th Annual International Conference on Digital Government Research, 282-291. OTORITAS JASA KEUANGAN (2014), Strengthening Economic Foundation Through Financial Inclusion, Retrieved from: https://www.ojk.go.id/. OTORITAS JASA KEUANGAN (2017), Laku Pandai (Layanan Keuangan Tanpa Kantor dalam Rangka Keuangan Inklusif), Retrieved from: https://www.ojk.go.id/.

RACHMAWATI R. (2009), ICT Based Services in Bank Sector and Its Benefit For Citizens in Yogyakarta Municipality, Indonesia, Proceeding of International Industrial Informatics Seminar (Book 2) 1 (1), 113-118.

RACHMAWATI R., ETTEMA D., RIJANTA R., DJUNAEDI A. (2010), The Impact of ICT

Use to The Change of Work Pattern and Its Relationship With work Travel, Proceeding World Academy of Science, Engineering, and Technology 66, 2587-2607.

RACHMAWATI R., RIJANTA R. (2012), Population Mobility and Urban Spatial Structure: Does the Use of Information and Communication Technology Matter?, Regional Views 25, 9-19.

RACHMAWATI R. (2013), ICT Based-Urban Economic Services, in: Markandey K., Srinagesh B., Lonavath A. K. (eds.), Challenges of Urbanization in the 21st Century, Volume 1. Amenities and facilities in urban areas, Concept Publishing Company, New Delhi, pp. 267-276. RACHMAWATI R., RIJANTA R., DJUNAEDI A. (2015), Location Decentralization Due to the Use of Information and Communication Technology: Empirical Evidence from Yogyakarta, Indonesia, Human Geographies - Journal of Studies and Research in Human Geography 9 (1), 5-15.

RACHMAWATI R., HAPSARI S. A., CITA A. M. (2018), Virtual space utilization in the Digital SMEs Kampongs: Implementation of Smart City and Region, Human Geographies Journal of Studies and Research in Human Geography 12 (1), 41-53.

REAVES B., SCAIFE N., BATES A., TRAYNOR P., BUTLER K. R. B. (2015), Mo(bile) Money, Mo(bile) Problems: Analysis of Branchless Banking Applications in the Developing World, Proceedings of the 24th USENIX Security Symposium, 17-32.

SANTOSO B., AHMAD K. (2016), Islamic Microfinance Branchless Banking Model in Indonesia, Intellectual Discourse 24 (Special Issue), 409-433.

SHABIRAH I., ALDIANTO L. (2014), The Suitable Model of Branchless Banking Implementation in Indonesia, Journal of Business and Management 3 (6), 633-645.

SILVERMAN B. W. (1986), Density Estimation for Statistics and Data Analysis, Chapman \& Hall/CRC, London and New York.

STILWELL F. J. B. (1992), Understanding Cities and Regions: Spatial political economy, Pluto Press, Leichhardt.

UDELL G. F. (2009), Financial Innovation, Organizations, and Small Business Lending, in: Alessandrini P., Fratianni M., Zazzaro A. (eds.), The Changing Geography of Banking and Finance, Springer, New York, pp. 15-26.

WILSON V. (2014), Research Methods: Sampling, Evidence Based Library and Information Practice 9 (2), 45-47.

Initial submission: 30.10 .2018

Revised submission: 16.03.2019

Final acceptance: 28.05.2019

Correspondence: Department of Development Geography, Faculty of Geography, Universitas Gadjah Mada, Sekip Utara, Bulaksumur, Yogyakarta 55281, Indonesia.

Email: rinirachma@ugm.ac.id 